\section{REFERENCES}

1. Albano EA, Pizzo PA. Infectious complications in childhood acute leukemias. Pediatr Clin North Am 1988;35:873-901.

2. Pizzo PA, Rubin M, Freifeld A, Walsh TJ. The child with cancer and infection, I: empiric therapy for fever and neutropenia, and preventive strategies. J Pediatr 1991;119:679-694.

3. Pizzo PA, Rubin M, Freifeld A, Walsh TJ. The child with cancer and infection, II: nonbacterial infections. J Pediatr 1991;119:845-857.

4. Pizzo PA. Management of fever in patients with cancer and chemotherapy induced neutropenia. $N$ Engl J Med 1993;328:1323-1332.

5. Katz JA, Mustafa MM. Management of fever in granulocytopenic children with cancer. Pediatr Infect Dis J 1993;12:330-339.

6. Holzel H, de Saxe M. Septicemia in pediatric intensive care patients at the Hospital for Sick Children, Great Ormond Street. J Hosp Infect 1992;22:185-195.

7. Möttönen M, Uhari M, Lanning M, Tuokko H. Prospective controlled survey of viral infections in children with acute lymphoblastic leukemia during chemotherapy. Cancer 1995;75:1712-1717.

8. Carlisle PS, Gucalp R, Wiernik PH. Nosocomial infections in neutropenic cancer patients. Infect Control Hosp Epidemiol 1993;14:320-324.

9. Morrison VA, Peterson BA, Bloomfield CD. Nosocomial septicemia in the cancer patient: the influence of central venous access devices, neutropenia and type of malignancy. Med Pediatr Oncol 1990;18:209-216.

10. Rotstein C, Cummings $\mathrm{KM}$, Nicolaou AL, Lucey J, Fitzpatrick J. Nosocomial infection rates at an oncology center. Infect Control Hosp Epidemiol 1988;9:13-19.

11. Doullioud D, Combe F, Latour JF, Chauvin F, Bigot P. Incidence of nosocomial infections in an anticancer center: clinical and bacteriological data. Bull Cancer 1990;77:893-900.

12. Velasco E, Santos Thuler LC, de St Martins CA, de Castro Dias LM, Goncalves VM. Nosocomial infections in an oncology intensive care unit. Am J Infect Control 1997;26:458-462.

13. Centers for Disease Control and Prevention. National Nosocomial Infections Surveillance (NNIS) report, data summary from October 1986-April 1998, issued June 1998. Am J Infect Control 1998;26:522-533.

14. Van Hoff J, Berg AT, Seashore JH. The effect of right atrial catheters on infectious complications of chemotherapy in children. J Clin Oncol 1990;8:1255-1262.

15. Kellerman S, Shay DK, Howard J, Feusner J, Rosenberg J, Vugia DJ, et al. Bloodstream infections in home infusion patients: the influence of race and needleless intravascular access devices. J Pediatr 1996;129:711717.

16. Creutzig U, Henze G, eds. Diagnostic and Therapeutic Standards in Pediatric Oncology. Munich, Germany: Zuckerschwerdt Verlag; 1997.

17. Tollemar J, Höckersted $\mathrm{K}$, Ericzon BG, Jalamko H, Ringden $\mathrm{O}$. Liposomal amphotericin $\mathrm{B}$ prevents invasive fungal infections in liver transplant recipients. Transpl 1995;59:45-50.
18. Conneally E, Cafferkey MT, Daly PA, Keane DT, McCann SR. Nebulized amphotericin $B$ as prophylaxis against invasive aspergillosis in granulocytopenic patients. Bone Marrow Transplant 1990;5:403-406.

19. Loo VG, Bertrand C, Dixon C, Vitye D, DeSalis B, McLean APH, et al Control of construction-associated nosocomial aspergillosis in an antiquated hematology unit. Infect Control Hosp Epidemiol 1996;17:360-364.

20. Garner JS, Jarvis WR, Emori TG, Horan TC, Hughes JM. CDC Definitions for nosocomial infections. Am J Infect Control 1988;16:128140.

21. Simon A Abteilung für allgemeine Pädiatrie und Poliklinik. Zentrum für Kinder heilkunde der Universität Bonn. http://www.meb.unibonn.de/institute/zenkin/hyg/hyg.html.

22. Mathers LH, Frankel LR. Stabilization of the critically ill child. In: Behrman RE, Kliegman RM, Jenson HB, eds. Nelson Textbook of Pediatrics. 16th ed. Philadelphia, PA: WB Saunders Company; 1999:252 (Table 64.5).

23. Emori TG, Culver DH, Horan TC. National Nosocomial Infections Surveillance (NNIS): description of surveillance methods. Am I Infect Control 1991;19:19-35.

24. The Hospital Infection Control Practices Advisory Committee. Guideline for prevention of intravascular device-related infections. $A m J$ Infect Control 1996;24:262-293.

25. Flynn PM, Shenep JL, Strokes DC, Barrett FF. In situ management of confirmed central venous catheter-related bacteriemia. Pediatr Infect Dis I 1987;6:729-734.

26. Kellerman S, Chans J, Jarvis W. Use of urokinase in pediatric hematology/oncology patients. Am I Infect Control 1998;26:502-506.

27. Lange B, Weiman M, Feuer EJ, Jakobowski D, Bilodeau J, Stallings VA, et al. Impact of changes in catheter management on infectious complications among children with central venous catheters. Infect Control Hosp Epidemiol 1997;18:326-332.

28. Wolfhagen MJ, Meijer K, Fluit AC, Torensma R, Bruinsma RA, Fleer A et al. Clinical significance of Clostridium difficile and its toxins in feces of immunocompromised children. Gut 1994;35:1608-1612.

29. Burgner D, Siarakas S, Eagles G, McCarthy A, Bradbury R, Stevens M. A prospective study of Clostridium difficile infection and colonization in pediatric oncology patients. Pediatr Infect Dis J 1997;16:1131-1134.

30. Gerding D, Johnson S, Peterson L, Mulligan M, Silva J. Clostridium difficile-associated diarrhea and colitis. Infect Control Hosp Epidemiol 1995;16:459-477.

31. Gorelick MH, Owen WC, Seibel NL, Reaman GH. Lack of association between neutropenia and the incidence of bacteremia associated with indwelling central venous catheters in febrile pediatric cancer patients. Pediatr Infect Dis J 1991;10:506-510.

32. Lucas KG, Brown AE, Armstrong D, Chapman D, Heller G. The identification of febrile, neutropenic children with neoplastic disease at low risk for bacteriemia and complications of sepsis. Cancer 1996;77:791-798.

\title{
Low Prevalence of MRSA in Community: New York City
}

\section{Gina Pugliese, RN, MS \\ Martin S. Favero, PhD}

Recent reports indicate that communityacquired methicillin-resistant Staphylococcus aureus (MRSA) infections are increasing and may now involve persons without risk factors predisposing for acquisition. To estimate the extent of community MRSA in New York City, Shopsin and colleagues from the Public Health Res

earch Institute, Tuberculosis Center and Department of Microbiology, New
York University Medical Center, determined the prevalence of $S$ aureus and MRSA nasal colonization in a well-patient population of 500 children and guardians. The prevalence of $S$ aureus nasal carriage was $35 \%$ for children and $28 \%$ for guardians. One person with predisposing risk factors was colonized with an MRSA. which was identified as the predominant clone found in New York City hospitals. A high degree of methicillin-susceptible $S$ aureus strain diversity was noted, with no apparent selection for specific clonal types.
The authors concluded that MRSA colonization is not ubiquitous in persons without predisposing risk outside of the healthcare environment. Bacterial competition and a lack of strong selection may limit the community spread of MRSA and can account for its sporadic distribution.

FROM: Shopsin B, Mathema B, Martinez J, Ha E, Campo ML, Fierman A, et al. Prevalence of methicillin-resistant and methicillin-susceptible Staphylococcus aureus in the community. I Infect Dis 2000; $182: 359-362$ 